\title{
High-fat concentration diets provided by different sources. Effect on thymus fatty acids composition in adult rats
}

\author{
C. Silva, P. Perris, I. Fernandez, N. Pellegrino, C. Mambrin, N. H. Slobodianik and M. S. Feliu \\ Department of Nutrition, Faculty of Pharmacy and Biochemistry, University of Buenos Aires, Argentina
}

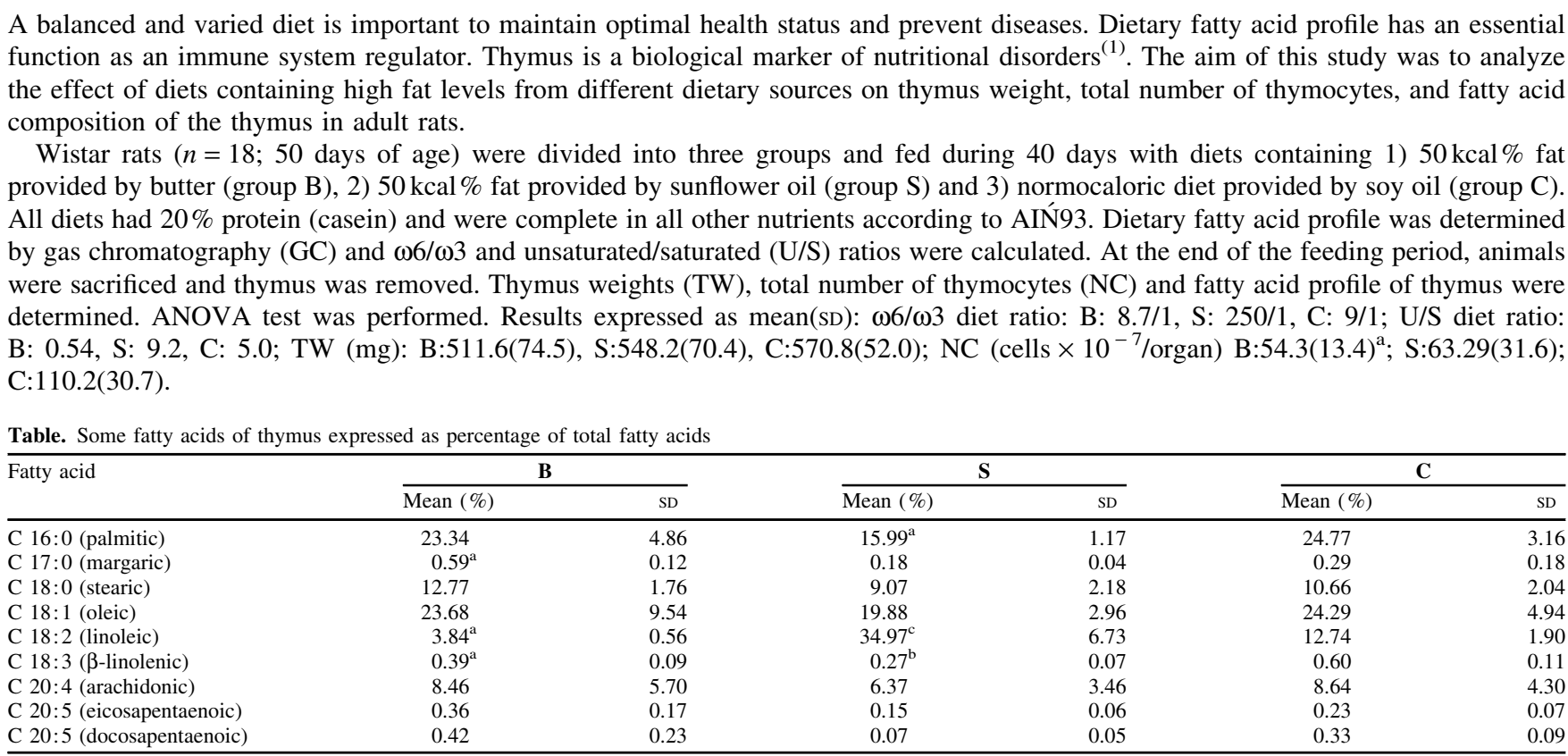

$(\mathrm{a}=p<0.05 ; \mathrm{b}=p<0.01 ; \mathrm{c}=p<0.001)$

Thymus weight was no statistically different in both experimental groups. Total number of thymocytes in B was lower than in C. Thymus cells from B group showed lower levels of $\alpha$-linolenic and linoleic acids and higher levels of margaric acid than in C; whereas $\mathrm{S}$ group showed lower levels of palmitic and $\beta$-linolenic acids, and higher linoleic concentration than $\mathrm{C}$. The differences on fatty acid composition of cell thymus in adults rats would be a consequence of the differences in these 3 dietary fatty acid profiles: altered $\omega 6 / \omega 3$ ratio in $S$ group and altered $\mathrm{U} / \mathrm{S}$ ratio in group $\mathrm{B}$, and a higher fat percentage in $\mathrm{B}$ and $\mathrm{S}$ diet in comparison with $\mathrm{C}$.

Supported by: UBA N ${ }^{\circ} 20020100200078$.

1. Marcos A (2012) Inmunonutrición en la salud y la enfermedad (Immunonutrition in Health and Disease) Ed. Médica Panamericana, Madrid, Spain. 